\title{
Statens helseundersøkelser og Tromsø
}

\author{
Egil Arnesen
}

\section{BAKGRUNN}

Etter 2. Verdenskrig økte arteriosklerotisk hjertesykdom eksplosivt i Vest-Europa og USA, endog slik at middellevetiden for menn sank. Internasjonalt hadde blant andre "Framingham-undersøkelsene", "Whitehall study" og "Seven countries study" satt fokus på serumkolesterol, blodtrykk og røyking som de tre viktigste forklaringsvariablene for denne epidemien og en forsøkte å redusere nivået av disse faktorene for å redusere sykeligheten. I løpet av 1970-årene ble det klart at epidemien ikke lenger hadde samme kraft, og begynte sakte å avta.

Norge skilte seg ikke ut fra denne trend. Imidlertid kunne en konstatere at det var betydelige forskjeller $\mathrm{i}$ dødelighet av arteriosklerotisk hjertesykdom mellom fylkene og at disse økte i løpet av 1960-årene. I analysen av dødelighetsforholdene i fylkene i perioden 1964-67, viser Statistisk Sentralbyrå (1) at forskjellene i dødelighet mellom fylkene er betydelig. Figur 1 viser at Nord-Norge sammen med Oslo og Bergen, de to største norske byene, hadde høyest mortalitet av arteriosklerotisk hjertesykdom, mens Hedmark, Oppland og Sogn og Fjordane hadde lavest. Dette var den erkjente situasjon da planleggingen av Oslo-undersøkelsen startet på initiativ av Paul Leren. Denne studien ble mal for de senere hjerte-karstudier i Norge. Kjell Bjartveit har i sin avhandling beskrevet andre hjertekarepidemiologiske studier i Norge som var gjort på dette tidspunkt (2).

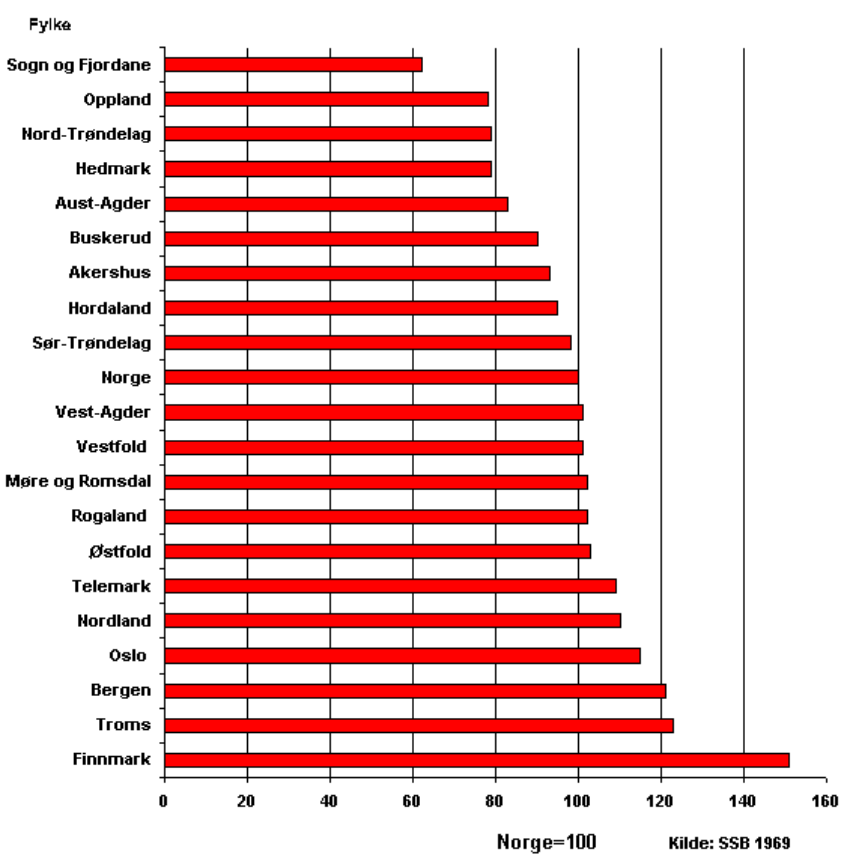

Figur 1. Aldersjustert dødelighet for ateriosklerotisk hjertesykdom etter fylke. Menn i alderen 40-69 år. Norge 1964-1967.
I 1971 ble det første norske professorat i epidemiologi og medisinsk statistikk opprettet. Det skjedde ikke i Oslo, Bergen eller Trondheim, men i Tromsø hvor det tredje medisinske fakultet var vedtatt opprettet av Stortinget i 1968. Både organiseringen av fakultetet og den medisinske studieplan var radikalt forskjellig fra hva som fantes ved de andre fakultetene i Norge. Den ideologiske basis for fakultetet var nedtegnet i studieplanen for legestudiet (3) og Målsettingskomiteens innstilling (4) og framhevet ønsket om at forskningen skulle være landsdelsrelevant og ta utgangspunkt vanlige folks problemer.

Knut Westlund ble tilsatt i professoratet i epidemiologi og medisinsk statistikk. Han kom ikke fra noen universitetsstilling, men fra Livsforsikringsselskapenes Medisinsk-statistiske institutt lokalisert på Ullevål sykehus. Derfra hadde han drevet omfattende epidemiologiske studier, også innen hjerte-karepidemiologi, og veiledet mange av de som hadde gjennomført klinisk epidemiologiske undersøkelser i Norge etter 1950-årene. Han var med i planleggingen av Osloundersøkelsen.

Da han kom til Tromsø, tok professor i indremedisin Arne Nordøy, initiativet til en hjerte-karscreening $i$ Tromsø. Westlund var med i planleggingen og sørget for at den ble gjennomført etter samme mal som Osloundersøkelsen. Prosjektet passet som hånd i hanske til kravet om å ta opp og prøve å gjøre noe med et medisinsk problem som folk i landsdelen mente var viktig. Videre var det et område som internasjonalt var omfattet med stor interesse. Daværende universitetslektor Dag Steinar Thelle og stipendiat Olav Helge Førde fikk oppdraget med å foreta den praktiske tilrettelegging og gjennomføring (5).

\section{SAMARBEIDET MELLOM INSTITUTT FOR SAMFUNNSMEDISIN (ISM) OG STATENS SKJERMBILDE-FOTOGRAFERING (SENERE OMDØРT TIL STATENS HELSUNDERSØKEL- SER (SHUS)) STARTER}

Mens planleggingen av Tromsøundersøkelsen var i gang, tok fylkeslegen i Finnmark, Kolbjørn Øygard, opp spørsmålet om ikke den høye hjerte-karsykeligheten i Finnmark burde medføre at en introduserte et forebyggende program i Finnmark. Det forebyggende programmet tok utgangspunkt i det program som tidligere distriktslege Anders Forsdahl (på daværende tidspunkt amanuensis, senere professor) hadde gjennomført i Bugøynes i Finnmark $(6,7)$. Universitetet i Tromsø støttet søknaden. Det ble nedsatt en styringsgruppe med representanter for Statens skjermbildefotografering, Universitetet i Tromsø og Fylkeslegen i 
Finnmark for å lage protokoll for undersøkelsen og senere oppfølging av screeningundersøkelsene. Statens skjermbildefotografering skulle gjennomføre screeningen og ha sekretariatsfunksjonen for undersøkelsen. Flere detaljer om dette i forordet til ISM skriftserie nr. 58 (8). Statens skjermbildefotografering hadde nå en "pakke" for forebygging av hjerte-karsykdommer, og dette ble etter hvert "solgt" som et helsetilbud. Det ble utarbeidet informasjonsmateriale til befolkningen og til de leger som skulle foreta oppfølging av enkeltpasienter, men dette er beskrevet $i$ andre artikler og jeg går ikke nærmere inn på det.

Selv om den formelle styringsgruppa var liten (Anders Forsdahl, Kjell Bjartveit og Kolbjørn Øygard), deltok vi "menige" fra ISM i diskusjonene på møtene. Som regel kom man til enighet uten for stor opphisselse. Men da vi forslo at en skulle spørre om bruk av p-piller, sa Statens skjermbildefotografering kontant nei. Man mente at spørsmålet var sensitivt og at det ville gå ut over frammøte. Først etter at vi hadde brukt det uten problem i Tromsøundersøkelsen i 1979-80, ble det akseptert som en opplysning som kunne samles inn.

\section{SAMARBEIDET FORSTERKES}

Ved ISM så vi at hjerte-karundersøkelsene som Statens skjermbildefotografering gjennomførte var vel standardiserte og profesjonelt utført. Vi var derfor ikke i tvil om at neste Tromsø-undersøkelse skulle foregå i nært samarbeid med dem. I 1979-80 foregikk den andre Tromsøundersøkelsen, og mer enn 16000 ble undersøkt. Vi var lettet over å slippe å bygge opp egne screeningteam og overlot det vesentlige av primærscreeningen til Statens skjermbildefotografering supplert med eget personell og eget laboratorium.

Ved alle de senere undersøkelsene, dvs i 1979-80, 1986-7, 1994-5 og i 2001, har derfor Statens skjermbildefotografering (senere SHUS) vært brukt til pri- mærscreening av befolkningen, og vi har supplert med egne tilleggsundersøkelser. Vi ville ikke klart å gjennomføre undersøkelsene med det omfang de har fått, uten samarbeidet med SHUS. Vi er vel også sikker på at SHUS lærte noe av samarbeidet med oss, og de fikk en lojal alliert når det gjaldt diskusjonen med myndighetene om midler til institusjonen. Vi har også samarbeid med SHUS i helseundersøkelser på Svalbard (9).

Utover i 1990-årene kom det mer langsiktige og forpliktende samarbeidet i forbindelse med etableringen av "COhort NORway" (CONOR) hvor Tromsøundersøkelsen inngikk som første delkohort i 1994-95, og vi etter hvert fikk kohorter fra Nord-Trøndelag, Hordaland og Oslo. For første gang hadde vi etablert et systematisk langsiktig samarbeid med utgangspunkt $i$ felles epidemiologiske data. De epidemiologiske miljøene i Oslo, Bergen, Trondheim og Tromsø hadde fått en felles plattform, samtidig som vi hadde lokal styringsrett over egne data. Etter dette har samarbeidet vært formalisert og relativt systematisk. Opprettingen av FUGE-plattformen har vært et foreløpig høydepunkt for arbeidet.

\section{DET VIDERE SAMARBEID}

Etableringen av Nasjonalt folkehelseinstitutt medførte at Statens helseundersøkelser forsvant som selvstendig organisasjon. CONOR-samarbeidet fortsetter inntil videre, men SHUS er delt opp og vi frykter at dets spesialkompetanse kan desintegreres og snart kan bli borte. Vi er forpliktet til å fortsette samarbeidet $\mathrm{i}$ FUGE-plattformen, men ledelsen av Folkehelseinstituttet har et annet syn på samarbeidet mellom de epidemiologiske miljøene enn det vi har utenfor Oslogryta. Hvordan Folkehelseinstituttet vil prioritere og videreutvikle den kompetanse SHUS hadde til å gjennomføre befolkningsrettete epidemiologiske studier, vil være avgjørende for samarbeidet $\mathrm{i}$ framtida.

\section{REFERANSER}

1. Statistisk Sentralbyrå. Dødelighetsforhold i fylkene 1964-1967. NOS A 298, 1969.

2. Bjartveit K, Foss OP, Gjervig T, Lund-Larsen PG. The cardiovascular disease study in Norwegian Counties. Background and organization. Acta Med Scand 1979; suppl 634.

3. Universitetet i Tromsø. Medisinsk studieplan, 1971.

4. Universitetet i Tromsø. Innstilling fra Målsettingskomiteen, 1972.

5. Thelle DS, Førde OH, Try K, Lehman EH. The Tromsø heart study. Methods and main results of the crosssectional study. Acta Med Scand 1976; 200: 107-18.

6. Forsdahl A, Salmi H. Finskættede i Sør-Varanger kommune - I. En undersøkelse av levekår, kostvaner, røykevaner $\mathrm{m} v \mathrm{i}$ en finskætted befolkningsgruppe. Tidsskr Nor Logeforen 1974; 94: 1561-5.

7. Forsdahl A, Salmi H, Forsdahl F, Ose L, Grundt I. Finskættede i Sør-Varanger kommune - II. En undersøkelse av blodtrykk, høyde, vekt, kolesterol, triglycerider og lipoproteinelektroforese blant finskættede menn samt effekten av kostendring. Tidsskr Nor Lageforen 1974; 94: 1565-72.

8. Forsdahl A, Fylkesnes K, Hermansen R, Lund E, Lupton B, Selmer R, Straume E. Hjerte-karundersøkelsene i Finnmark 1974-2000. Resultater fra undersøkelsene. ISM skriftserie nr 58, 2001.

9. Schirmer H, Høyer G, Nilssen O, Brenn T, Steine S. Helse og livskvaliteter på 78 grader nord. Rapport fra en befolkningsstudie på Svalbard høsten 1988. ISM skriftserie nr 40, 1997. 


\section{Publikasjoner fra Tromsø-undersøkelsene fram til og med 2002}

\section{Doktoravhandlinger:}

Olav Helge Førde og Dag Steinar Thelle. The Tromsø Heart Study. Population studies of coronary risk factors with special emphasis on high density lipoprotein and the family occurrence of myocardial infarction. Tromsø: ISM Skriftserie Nr. 4. Universitetet i Tromsø, 1979.

Jan Tore Gran. A clinical, radiological and epidemiological survey of ankylosing spondylitis. Tromsø: Universitetet i Tromsø (IKM), 1985.

Bjarne Koster Jacobsen. The use of self-administered questionnaires about food habits. Tromsø: ISM Skriftserie Nr. 11. Universitetet i Tromsø, 1988.

Jetmund Ringstad. Selenium in cardiovascular disease and cancer. Epidemiological and experimental studies. Tromsø: Universitetet i Tromsø (ISM/IKM), 1988.

Aage Tverdal. A mortality follow-up of persons invited to a cardiovascular disease study in five areas in Norway. Oslo: National Health Screening Service, 1989.

Synnøve Fønnebø Knutsen. The Tromsø survey: The family intervention study. Tromsø: ISM Skriftserie Nr. 17. Universitetet i Tromsø, 1990.

Arild Bjørndal. Forbruk av psykofarmaka i Norge. Kartlegging og analyser. Oslo: Seksjon for helsetjenesteforskning, SIFF. Rapport nr. 7, 1990.

Knut Fylkesnes. Factors affecting self-evaluated general health status - and the use of professional health care services. Tromsø: ISM Skriftserie Nr. 19. Universitetet i Tromsø, 1991.

Odd Nilssen. Serum gamma-glutamyltransferase: population determinants and diagnostic characteristics in relation to intervention on risk drinkers. Tromsø: ISM Skriftserie Nr. 20. Universitetet i Tromsø, 1991.

Vinjar Fønnebø. The healthy faith. Pregnancy outcome, risk of disease, cancer morbidity and mortality in Norwegian Seventh-Day Adventists. Tromsø: ISM Skriftserie Nr. 21. Universitetet i Tromsø, 1992.

Inger Torhild Gram. Aspects of breast and cervical cancer screening. Tromsø: ISM Skriftserie Nr. 22. Universitetet i Tromsø, 1992.

Roar Johnsen. Population studies on dyspepsia and peptic ulcer disease. Occurrence, aetiology, and diagnosis. From the Tromsø Heart Study and The Sørreisa Gastrointestinal Disorder Study. Tromsø: ISM Skriftserie Nr. 23. Universitetet i Tromsø, 1992.

Kaare H. Bønaa. Relationship between hemodynamics and blood lipids in population surveys, and effects of n-3 fatty acids. Tromsø: ISM Skriftserie Nr. 25. Universitetet i Tromsø, 1992.

Anne Elise Eggen. Patterns and predictors of drug use. A pharmacoepidemiologic study, linking the analgesic drug prescriptions to a population health survey in Tromsø, Norway. Tromsø: ISM Skriftserie Nr. 29. Universitetet i Tromsø, 1994.

Maja-Lisa Løchen. Arrhythmia, electrocardiographic signs, and physical activity in relation to coronary heart risk factors and disease. The Tromsø Study. Tromsø: ISM Skriftserie Nr. 31. Universitetet i Tromsø, 1995.

Toralf Hasvold. Headache and neck or shoulder pain. An analysis of problems in three comprehensive population studies in Northern Norway. Tromsø: ISM Skriftserie Nr. 38. Universitetet i Tromsø, 1996.

Inger Thune. Physical activity and risk of cancer. A population based cohort study including prostate, testicular, colorectal, lung and breast cancer. Tromsø: ISM Skriftserie Nr. 41. Universitetet i Tromsø, 1997.

Ingrid Toft. Metabolic changes in essential hypertension and glucose intolerance. Tromsø: Universitetet i Tromsø (IKM), 1998.

Ragnar Joakimsen. The Tromsø Study. Risk factors for non-vertebral fractures in a middle-aged population. Tromsø: ISM Skriftserie Nr. 47. Universitetet i Tromsø, 1999.

Henrik Schirmer. Echocardiographic screening in a general population. Normal distribution of echocardiographic measurements and their relation to cardiovascular risk factors and disease. The Tromsø Study. Tromsø: ISM Skriftserie Nr. 49. Universitetet i Tromsø, 2000.

Oddmund Joakimsen. Ultrasound assessed carotid atherosclerosis in a general population. The Tromsø Study. Tromsø: ISM Skriftserie Nr. 52. Universitetet i Tromsø, 2000.

Eva Stensland-Bugge. Risk factors for carotid intima-media thickness in a general population. The Tromsø Study 1979-1994. Tromsø: ISM Skriftserie Nr. 53. Universitetet i Tromsø, 2000. 
Tone Smith-Sivertsen. Air pollution and health in the Norwegian-Russian border area. A cross-sectional population-based study of the impact of nickel and sulphur dioxide. Tromsø: ISM Skriftserie Nr. 55. Universitetet i Tromsø, 2000.

Gro K. Rosvold Berntsen. Interpretation of forearm bone mineral density. The Tromsø Study. Tromsø: ISM Skriftserie nr 56. Universitetet i Tromsø, 2000.

Sameline Grimsgaard. Individual fatty acids and cardiovascular risk factors. Tromsø: ISM Skriftserie Nr 57. Universitetet i Tromsø, 2001.

Ellisiv B. Mathiesen. The stenotic carotid artery plaque. Prevalence, risk factors and relations to clinical disease. The Tromsø Study. ISM Skriftserie Nr. 60. Universitetet i Tromsø, 2001.

Vidje Hansen. Psychiatric morbidity and mortality in Northern Norway in the era of deinstitutionalisation. A psychiatric case register study. ISM Skriftserie Nr. 63. Universitetet i Tromsø, 2001.

Tom Wilsgaard. Longitudinal analyses of cardiovascular risk factors. The Tromsø Study 1974-1995. ISM Skriftserie Nr. 65. Universitetet i Tromsø, 2002.

\section{Hovedfagsoppgaver:}

Reidun Therese Jensen og Steffen Jacobsen. Risikoidentifisering - på godt og vondt. Opplevelser knyttet til ultralydundersøkelse for hjerte- og karsykdommer. Institutt for psykologi, Universitetet i Tromsø, 1998. (hovedoppgave 5. årsenhet)

Vibeke Fagernes. Legemiddelbruk hos diabetikere: Selvrapportert legemiddelbruk og helsetilstand hos diabetikere i Tromsø kommune. Institutt for farmasi, Universitetet i Tromsø, 2001.

Anne-Lise Paulsen. Har kvinner dårligere psykisk helse enn menn? Selvrapportert psykisk helse og medikamentbruk i en generell befolkning. Institutt for farmasi, Universitetet i Tromsø, 2001.

Dag Stokke. Medikamentell behandling av personer med diabetes: bruk av hjerte- og karlegemidler og etterlevelse av behandlingsmål. Tromsøundersøkelsen 1994-95. Institutt for farmasi, Universitetet i Tromsø, 2002.

\section{Artikler:}

(tall i parentes refererer til Tromsøundersøkelsene I-IV)

\section{6-1983:}

Thelle DS, Førde OH. The Tromsø Heart Study. Methods and main results of the cross-sectional study. Acta Med Scand 1976; 200: 107-118. (I)

Førde OH, Thelle DS. The Tromsø Heart Study: risk factors for coronary heart disease related to the occurrence of myocardial infarction in first degree relatives. Am J Epidemiol 1977; 105: 192-199. (I)

Miller NE, Førde OH, Thelle DS, Mjøs OD. The Tromsø Heart Study. High-density lipoprotein and coronary heart disease: a prospective case-control study. Lancet 1977; i: 965-968. (I)

Mjøs OD, Thelle DS, Førde OH, Vik-Mo H. Family study of high density lipoprotein cholesterol and the relation to age and sex. Acta Med Scand 1977; 201: 323-329. (I)

Førde OH, Thelle DS, Miller NE, Mjøs OD. The Tromsø Heart Study. Distribution of serum cholesterol between high density and lower density lipoproteins in subjects of Norse, Finnish and Lappish ethnic origin. Acta Med Scand 1978; 203: 21-26. (I)

Ishikawa T, Fidge N, Thelle DS, Førde OH, Miller NE. The Tromsø Heart Study: serum apolipoprotein AI concentration in relation to future coronary heart disease. Eur J Clin Invest 1978; 8: 179-182. (I)

Thelle DS, Førde OH. The Tromsø Heart Study: the consequences of blood pressure screening in men aged 20-49 years. Acta Med Scand Suppl 1979; 626: 13-16. (I)

Vik B, Try K, Thelle DS, Førde OH. Tromsø Heart Study: vitamin D metabolism and myocardial infarction. BR MED J 1979; 282: 176-177. (I)

Førde OH, Thelle DS. The Tromsø Heart Study. A multiple regression analysis of the relationship between coronary risk factors and some physical and social variables. Scand J Soc Med 1980; 8: 49-54. (I)

Thelle DS, Arnesen E, Førde OH. The Tromsø Heart Study. Does coffee raise serum cholesterol? N Engl J Med 1983; 308: 1454-1457. (II) 


\section{4:}

Arnesen E, Førde OH, Thelle DS. Coffee and serum cholesterol. BR MED J 1984; 288: 1960.

Gran JT, Husby G. Ankylosing spondylitis. A comparative study of patients in an epidemiological survey, and those admitted to a department of rheumatology. J Rheumatol 1984; 11: 788-793. (II)

Gran JT, Hordvik M, Husby G. Roentgenological features of ankylosing spondylitis. A comparison between patients attending hospital and cases selected through an epidemiological survey. Clin Rheumatol 1984; 3: 467-472. (II)

Gran JT, Husby G, Hordvik M, Størmer J, Romberg-Andersen Ø. Radiological changes in men and women with ankylosing spondylitis. Ann Rheum Dis 1984; 43: 570-575. (II)

Gran JT, Johannessen A, Husby G. A study of IgM rheumatoid factor in a middle-aged population of Northern Norway. Clin Rheumatol 1984; 3: 163-168. (II)

Gran JT, Husby G, Johannessen A. Epidemiologiske og genetiske aspekter ved revmatoide faktorer. Tidsskr Nor Lægeforen 1984; 104: 1222-1224. (II)

Gran JT, Husby G. Symptomer og funn ved Bechterews sykdom. Tidsskr Nor Lægeforen 1984; 104: 1291-1294. (II)

Kavli G, Førde OH. Hand dermatoses and sick-leave: relationship between educational level, physical activity at work and housework as main occupation. Contact Dermatitis 1984; 11: 70-73. (II)

Kavli G, Førde OH. Hand dermatoses in Tromsø. Contact Dermatitis 1984; 10: 174-177. (II)

\section{5:}

Arnesen E, Forsdahl A. The Tromsø Heart Study: coronary risk factors and their association with living conditions during childhood. J Epidemiol Community Health 1985; 39: 210-214. (II)

Brenn T, Arnesen E. Selecting risk factors: a comparison of discriminant analysis, logistic regression and Cox's regression model using data from the Tromsø Heart Study. Stat Med 1985; 4: 413-423. (I)

Fønnebø V. The Tromsø Heart Study: coronary risk factors in Seventh-Day Adventists. Am J Epidemiol 1985; 122: 789-793.

Førde OH, Knutsen SF, Arnesen E, Thelle DS. The Tromsø Heart Study: coffee consumption and serum lipid concentrations in men with hypercholesterolaemia: a randomised intervention study. BR MED J 1985; 290: 893-895. (II)

Gran JT. An epidemiological survey of the signs and symptoms of ankylosing spondylitis. Clin Rheum 1985; 4: 161-169. (II)

Gran JT, Husby G, Hordvik M. Prevalence of ankylosing spondylitis in males and females in a young middleaged population of Tromsø, northern Norway. Ann Rheum Dis 1985; 44: 359-367.(II)

Gran JT, Husby G, Hordvik M. Spinal ankylosing spondylitis: a variant form of ankylosing spondylitis or a distinct disease entity? Ann Rheum Dis 1985; 44: 368-371.(II)

Gran JT, Østensen M, Husby G. A clinical comparison between males and females with ankylosing spondylitis. J Rheumatol 1985; 12: 126-129. (II)

Gran JT, Husby G, Thorsby E. The prevalence of HLA-DR4 and HLA-DR3 in healthy persons with rheumatoid factor. Scand J Rheumatol 1985; 14: 79-82. (II)

Gran JT, Gaarder PI, Husby G. IgG heavy chain (Gm) allotypes in ankylosing spondylitis. Clin Rheum 1985; 4: 73-75. (II)

Kavli G, Førde OH, Arnesen E, Stenvold SE. Psoriasis: familial predisposition and environmental factors. BR MED J 1985; 291: 999-1000. (II)

\section{6:}

Arnesen E, Huseby NE, Brenn T, Try K. The Tromsø Heart Study: distribution of, and determinants for, gammaglutamyltransferase in a free-living population. Scand J Clin Lab Invest 1986; 46: 63-70. (II)

Brenn T. The Tromsø Heart Study: alcoholic beverages and coronary risk factors. J Epidemiol Community Health 1986; 40: 249-256. (II)

Gran JT, Lerang F, Lægreid IK, Hansen J, Husby G, Hordvik M. Epidemiologiske forhold ved Bechterews sykdom. Tidsskr Nor Lægeforen 1986; 106: 1677-1679. (II) 
Gran JT, Østensen M, Husby G. Bechterews sykdom hos kvinner. Tidsskr Nor Lægeforen 1986; 106: 2235-2237. (II)

Johnsen R, Jacobsen BK, Førde OH. Associations between symptoms of irritable colon and psychological and social conditions and lifestyle. BR MED J 1986; 292: 1633-1635. (II)

\section{7:}

Gran JT, Husby G. On the prevalence of ankylosing spondylitis. (Letter). J Rheumatol 1987; 14: 174-175. (II)

Jacobsen BK, Thelle DS. The Tromsø Heart Study: food habits, serum total cholesterol, HDL cholesterol, and triglycerides. Am J Epidemiol 1987; 125: 622-630. (II)

Jacobsen BK, Knutsen SF, Knutsen R. The Tromsø Heart Study: Comparison of information from a short food frequency questionnaire with a dietary history survey. Scand J Soc Med 1987; 15: 41-47. (II)

Jacobsen BK, Thelle DS. The Tromsø Heart Study: Is coffee drinking an indicator of a life style with high risk for ischemic heart disease? Acta Med Scand 1987; 222: 215-221. (II)

Jacobsen BK, Thelle DS. The Tromsø Heart Study: the relationship between food habits and the body mass index. J Chron Dis 1987; 40: 795-800. (II)

Jacobsen BK, Bønaa KH. Re: Employment status and women's protection against coronary heart disease. Letter. Am J Epidemiol 1987; 126: 159-160.

Ringstad J, Jacobsen BK, Thomassen Y. The Tromsø Heart Study: Relationships between the concentration of selenium in serum and risk factors for coronary heart disease. J Trace Elem Electrolytes Health Dis 1987; 1: 27-31. (II)

Ringstad J, Fønnebø V. The Tromsø Heart Study: serum selenium in a low-risk population for cardiovascular disease and cancer and matched controls. Ann Clin Res 1987; 19: 351-354. (II)

Ringstad J, Jacobsen BK, Thomassen Y, Thelle DS. The Tromsø Heart Study: serum selenium and risk of myocardial infarction in a nested case-control study. J Epidemiol Community Health 1987; 41: 329-332. (II)

Thelle DS. Kaffe og kolesterol. Gjennomgang av publiserte epidemiologiske og eksperimentelle undersøkelser. Tidsskr Nor Lægeforen 1987; 107: 2429-2430. (II)

Thelle DS, Heyden S, Fodoer JG. Coffee and cholesterol in epidemiological and experimental studies. Review article. Atherosclerosis 1987; 67: 97-103. (II)

Tretli S, Langmark F, Thelle DS. Har De noen gang hatt kreftsykdom? En sammenligning av svar på dette spørsmål gitt ved hjerte- og karundersøkelsen i Tromsø og data registrert ved Kreftregisteret. Tidsskr Nor Lægeforen 1987; 107: 1780-1782. (II)

Tverdal A. Systolic and diastolic blood pressures as predictors of coronary heart disease in middle aged Norwegian men. BR MED J 1987; 294: 671-673. (I)

\section{8:}

Bønaa KH, Arnesen E, Thelle DS, Førde OH. Coffee and cholesterol: is it all in the brewing? The Tromsø Study. BMJ 1988; 297: 1103-1104. (III)

Fønnebø V. The Tromsø Heart Study. Diet, religion and risk factors for coronary heart disease. Am J Clin Nutr 1988; 48: 826-829. (II)

Jacobsen BK, Hansen V. Caffeine and health. Letter. BMJ 1988; 296: 291. (II)

Jacobsen BK, Thelle DS. The Tromsø Heart Study: responders and non-responders to a health questionnaire, do they differ? Scand J Soc Med 1988; 16: 101-104.(II)

Jacobsen BK, Thelle DS. Risk factors for coronary heart disease and level of education. The Tromsø Heart Study. Am J Epidemiol 1988; 127: 923-932. (II)

Johnsen R, Straume B, Førde OH. Peptic ulcer and non-ulcer dyspepsia - a disease and a disorder. Scand J Prim Health Care 1988; 6: 239-243. (II)

Løchen ML. The Tromsø Heart Study: coronary risk factor levels in treated and untreated hypertension. Acta Med Scand 1988; 224: 515-521. (II)

Ringstad J, Jacobsen BK, Tretli S, Thomassen Y. Serum selenium concentration associated with risk of cancer. J Clin Pathol 1988; 41: 454-457. (II) 


\section{9:}

Bjørndal A, Forsén L. En pille for alt som er ille? En analyse av psykofarmakaforbruket i Helseundersøkelsen i Nord-Trøndelag 1984-86. Seksjon for helsetjenesteforskning, SIFF Rapport nr. 7/1989. (III)

Gram IT, Lund-Larsen PG, Rosenlund AF, Størmer J. Mammografiscreening i Tromsø. Gjennomføring og resultat av den første mammografiscreening i Norge. Tidsskr Nor Lægeforen 1989; 109: 1040-1042. (III)

Hansen V, Jacobsen BK. Mental distress and social conditions and lifestyle in northern Norway. BMJ 1989; 299: 85-88. (II)

Jacobsen BK. Frequency of alcohol use and the level of education. J Intern Med 1989; 225: 417-422. (II)

Jacobsen BK, Hansen V. Mental problems and frequent use of analgesics. Letter. Lancet 1989; i: 273. (II)

Knutsen SF, Knutsen R. The Tromsø Heart Study: Family approach to intervention on CHD. Scand J Soc Med 1989; 17: 109-119. (II)

\section{0:}

Bønaa KH, Bjerve KS, Straume B, Gram IT, Thelle D. Effect of eicosapentaenoic and docosahexaenoic acids on blood pressure in hypertension. A population-based intervention trial from the Tromsø Study. N Engl J Med 1990; 322: 795-801. (III)

Gram IT, Lund E, Slenker SE. Quality of life following a false positive mammogram. Br J Cancer 1990; 62: 10181022. (III)

Husby R, Lingjærde O. Prevalence of reported sleeplessness in northern Norway in relation to sex, age and season. Acta Psychiatr Scand 1990; 81: 542-547. (II)

Jacobsen BK, Bønaa KH. The reproducibility of dietary data from a self-administered questionnaire. The Troms $\varnothing$ Study. Int J Epidemiol 1990; 19: 349-353. (III)

Jacobsen BK, Lund E. Level of education, use of oral contraceptives and reproductive factors: The Tromsø study. Int J Epidemiol 1990; 19: 967-970. (III)

Knutsen SF, Knutsen R. Wives of coronary high-risk men - are they also at higher risk? The Tromsø Heart Study. J Intern Med 1990; 228: 333-337. (II)

Nilssen O, Førde OH, Brenn T. The Tromsø Study. Distribution and population determinants of gammaglutamyltransferase. Am J Epidemiol 1990; 132: 318-326. (III)

\section{1:}

Bønaa K, Thelle DS. Association between blood pressure and serum lipids in a population. The Tromsø Study. Circulation 1991; 83: 1305-1314. (II)

Fylkesnes K, Førde OH. The Tromsø Study: Predictors of self-evaluated health - has society adopted the expanded health concept? Soc Sci Med 1991; 32: 141-146. (III)

Hansen V, Jacobsen BK, Husby R. Mental distress during winter. An epidemiologic study of 7759 adults north of Arctic Circle. Acta Psychiatr Scand 1991: 84: 137-141. (II)

Knutsen SF, Knutsen R. The Tromsø Survey: The Family Intervention Study. Effect of intervention on some coronary risk factors and dietary habits. 6-year follow up. Prev Med 1991; 20: 197-212. (II, III)

Løchen ML. The Tromsø Study: Associations between self-reported arrhythmia, psychological conditions, and lifestyle. Scand J Prim Health Care 1991; 9: 265-270. (III)

Nilssen O, Førde $\mathrm{OH}$. The Tromsø Study: the positive predictive value of gamma-glutamyltransferase and an alcohol questionnaire in the detection of early-stage risk drinkers. J Intern Med 1991; 229: 497-500. (III)

Nilssen O. The Tromsø Study: Identification of and a controlled intervention on a population of early-stage risk drinkers. Prev Med 1991; 20: 518-528. (III)

\section{2:}

Bønaa KH, Bjerve KS, Nordøy A. Docosahexaenoic and eicosapentaenoic acids in plasma phospholipids are divergently assoicated with high density lipoprotein in humans. Arterioscler Thromb 1992; 12: 675-681. (III)

Bønaa KH, Bjerve KS, Nordøy A. Habitual fish consumption, plasma phospholipid fatty acids, and serum lipids: the Tromsø Study. Am J Clin Nutr 1992; 55: 1126-1134. (III)

Bønaa KH, Arnesen E. Association between heart rate and atherogenic blood lipid fractions in a population. The Tromsø Study. Circulation 1992; 86: 394-405. (III) 
Gram IT, Austin H, Stalsberg H. Cigarette smoking and the incidence of cervical intra-epithelial neoplasia, grade III, and cancer of the cervix uteri. Am J Epidemiol 1992; 135: 341-346. (II)

Gram IT, Macaluso M, Stalsberg H. Oral contraceptive use and the incidence of cervical intraepithelial neoplasia. Am J Obstet Gynecol 1992; 167: 40-44. (II)

Gram IT, Slenker SE. Cancer anxiety and attitudes toward mammography among screening attenders, nonattenders, and women never invited. Am J Public Health 1992; 82: 249-251. (III)

Gram IT, Austin H, Stalsberg H. Cigarette smoking and the incidence of cervical intra-epithelial neoplasia, grade III, and cancer of the cervix uteri. Am J Epidemiol 1992; 135: 341-346. (II)

Johnsen R, Straume B, Førde OH, Burhol PG. Changing incidence of peptic ulcer - facts or artifacts? A cohort study from Tromsø. J Epidemiol Community Health 1992; 46: 433-436. (II)

Løchen ML. The Tromsø Study: the prevalence of exercise-induced silent myocardial ischaemia and relation to risk factors for coronary heart disease in an apparently healthy population. Eur Heart J 1992; 13: 728-731. (III)

Løchen ML, Rasmussen K. The Tromsø study: physical fitness, self reported physical activity, and their relationship to other coronary risk factors. J Epidemiol Community Health 1992; 26: 103-107. (III)

\section{3:}

Eggen AE. The Tromsø Study: frequency and predicting factors of analgesic drug use in a free-living population (12-56 years). J Clin Epidemiol 1993; 11: 1297-1304. (III)

Hasvold T, Johnsen R. Headache and neck or shoulder pain - frequent and disabling complaints in the general population. Scand J Prim Health Care 1993; 11: 219-224. (III)

\section{4:}

Eggen AE. Pattern of drug use in a general population: Prevalence and predicting factors. The Tromsø Study. Int J Epidemiol 1994; 23: 1262-1272. (III)

Johnsen R, Førde OH, Straume B, Burhol PG. On the etiology of peptic ulcer: a prospective population study. J Epidemiol Community Health 1994; 48: 156-160. (II)

Løchen ML, Snaprud T, Zhang W, Rasmussen K. Arrhythmias in subjects with and without a history of palpitations: the Tromsø study. Eur Heart J 1994; 15: 345-349. (III)

Nilssen $\mathrm{O}$, Førde $\mathrm{OH}$. Seven-year population study of change in gamma-glutamyltransferase: The Tromsø Study. Am J Epidemiol 1994; 139: 787-792. (II, III)

Thune I, Lund E. Physical activity and the risk of prostate and testicular cancer: a cohort study of 53,000 Norwegian men. Cancer Causes Control 1994; 5: 549-556. (I)

\section{5:}

Arnesen E, Refsum H, Bønaa KH, Ueland PM, Førde OH, Nordrehaug JE. Serum total homocysteine and coronary heart disease. Int J Epidemiol 1995; 24: 704-709. (III)

Gram IT, Funkhouser E, Tabár L. Reproductive and menstrual factors in relation to mammographic parenchymal patterns among perimenopausal women. Br J Cancer 1995; 71: 647-650. (III)

Toft I, Bønaa KH, Ingebretsen OC, Nordøy A, Jenssen T. Effects of n-3 polyunsaturated fatty acids on glucose homeostasis and blood pressure in essential hypertension. A randomized, controlled trial. Ann Intern Med 1995; 123: 911-918. (III)

\section{6:}

Bryhni B, Aanderud S, Sundsfjord J, Rekvig OP, Jorde R. Thyroid antibodies in northern Norway: prevalence, persistence and relevance. J Intern Med 1996; 239: 517-523. (II, III)

Eggen AE. The use of controlled analgesics in a general population (15-59 years) - the influence of age, gender, morbidity, lifestyle and sociodemographic factors. Pharmacoepid Drug Safety 1996; 5: 101-111. (III)

Hasvold T, Johnsen R, Førde OH. Non-migrainous headache, neck or shoulder pain, and migraine - differences in association with background factors in a city population. Scand J Prim Health Care 1996; 14: 92-99. (III)

Thune I, Lund E. Physical activity and risk of colorectal cancer in men and women. Br J Cancer 1996; 73: 11341140. (I) 


\section{7:}

Gram IT, Funkhouser E, Tabár L. Anthropometric indices in relation to mammographic patterns among perimenopausal women. Int J Cancer 1997; 73: 323-326. (III)

Gram IT, Riise T, Honda Y. Rheumatoid arthritis: a commonly misused diagnosis by the general population. Clin Rheumatol 1997; 16: 264-266. (II)

Gram IT, Funkhouser E, Tabar L. The Tabár classification of mammographic parenchymal patterns. Eur J Radiol 1997; 24: 131-136. (III)

Grimsgaard S, Bønaa KH, Hansen JB, Nordøy A. Highly purified eicosapentaenoic and docosahexaenoic acid in humans have similar triacylglycerol-lowering effects but divergent effects on serum fatty acids. Am J Clin Nutr 1997; 66: 649-659. (III)

Joakimsen O, Bønaa KH, Stensland-Bugge E. Reproducibility of ultrasound assessment of carotid plaque occurrence, thickness, and morphology. The Tromsø Study. Stroke 1997; 28: 2201-2207. (IV)

Stensland-Bugge E, Bønaa KH, Joakimsen O. Reproducibility of ultrasonographically determined intima-media thickness is dependent on arterial wall thickness. The Tromsø Study. Stroke 1997; 28: 1972-1980. (IV)

Thune I, Lund E. The influence of physical activity on lung-cancer risk. A prospective study of 81,516 men and women. Int J Cancer 1997; 70: 57-62. (I)

Toft I, Bønaa KH, Ingebretsen OC, Nordøy A, Jenssen T. Fibrinolytic function after dietary supplementation with (omega) 3 polyunsaturated fatty acids. Arterioscler Thromb Vasc Biol 1997; 17: 814-819. (III)

Toft I, Bønaa KH, Ingebretsen OC, Nordøy A, Birkeland KI, Jenssen T. Gender differences in the relationships between plasma plasminogen activator inhibitor-1 activity and factors linked to the insulin resistance syndrome in essential hypertension. Arterioscler Thromb Vasc Biol 1997; 17: 553-559. (III)

Tverdal A, Åsberg A, Bønaa KH, Stensvold I, Grudt G, Ingebretsen OH, Urdal P. Sammenligning av to blodprøver fra samme person analysert ved to laboratorier. Norsk Epidemiologi 1997; 7: 283-286.

\section{8:}

Grimsgaard S, Bønaa KH, Hansen JB, Myhre ES. Effects of highly purified eicosapentaenoic acid and docosahexaenoic acid on hemodynamics in humans. Am J Clin Nutr 1998; 68: 52-59. (III)

Joakimsen RM, Fønnebø V, Magnus JH, Tollan A, Søgaard AJ. The Tromsø Study: Body height, body mass index and fractures. Osteoporos Int 1998; 8: 436-442. (II, III, IV)

Joakimsen RM, Fønnebø V, Magnus JH, Størmer J, Tollan A, Søgaard AJ. The Tromsø Study: Physical activity and the incidence of fractures in a middle-aged population. J Bone Miner Res 1998; 13: 1149-1157 (II, III, IV)

Singh K, Bønaa KH, Solberg S, Sørlie DG, Bjørk L. Intra- and interobserver variability in ultrasound measurements of abdominal aortic diameter. The Tromsø Study. Eur Vasc Endovasc Surg 1998; 15: 497-504. (IV)

Smith-Sivertsen T, Tchachtchine V, Lund E, Bykov V, Thomassen Y, Norseth T. Urinary nickel excretion in populations living in the proximity of two Russian nickel refineries: A Norwegian-Russian population-based study. Environ Health Perspect 1998; 106: 503-511. (IV)

Thune I, Njølstad I, Løchen ML, Førde OH. Physical activity improves the metabolic risk profiles in men and women: The Tromsø Study. Arch Intern Med 1998; 158: 1633-1640. (II, III)

Toft I, Bønaa KH, Jenssen T. Insulin resistance in hypertension is associated with body fat rather than blood pressure. Hypertension 1998; 32: 115-122. (III)

Toft I, Bønaa KH, Lindal S, Jenssen T. Insulin kinetics, insulin action and muscle morphology in lean or slightly overweight persons with impaired glucose tolerance. Metabolism 1998; 47: 848-854. (III)

Wilsgaard T, Brenn T, Arnesen E. Tracking of blood pressure in adult men: the Tromsø Study 1974-1986. J Epidemiol Biostat 1998; 3: 269-273. (I, II, III)

\section{9:}

Berntsen GKR, Tollan A, Magnus JH, Søgaard AJ, Ringberg T, Fønnebø V. The Tromsø Study: Artifacts in forearm bone densitometry - Prevalence and effects. Osteoporos Int 1999; 10: 425-437. (IV)

Gram IT, Funkhouser E, Tabar L. Moderate physical activity in relation to mammographic patterns. Cancer Epidemiol Biomark Prev 1999; 8: 117-122. (II, III) 
Joakimsen O, Bønaa KH, Stensland-Bugge E, Jacobsen BK. Age and sex differences in the distribution and ultrasound morphology of carotid atherosclerosis. Arterioscler Thromb Vasc Biol 1999; 19: 3007-3013. (IV)

Jorde R, Bønaa KH, Sundsfjord J. Population based study on serum ionised calcium, serum parathyroid hormone, and blood pressure. The Tromsø study. Eur J Endocrin 1999; 141: 350-357. (IV)

Jorde R, Sundsfjord J, Fitzgerald P, Bønaa KH. Serum calcium and cardiovascular risk factors and diseases: the Tromsø study. Hypertension 1999; 34: 484-490. (IV)

Løchen ML, Rasmussen K, MacFarlane PW, Arnesen E. Can single lead computerized electrocardiography predict myocardial infarction in young and middle-aged men? The Tromsø Study. J Cardiovasc Risk 1999; 6: 273-278.

Løchen ML, Njølstad I. Blir kvinner utelatt fra medisinsk forskning? Myter og realiteter. Tromsø: Universitetet i Tromsø. Ottar 1999; Nr 226. 49-56. (III)

Løchen ML, Njølstad I. Does medical research ignore women? Myth and reality. (simultanpublikasjon). Tromsø: University of Tromsø. Ottar 1999; No 226. 49-56. (III)

Sexton H, Lipton RI, Nilssen O. Relating alcohol use and mood: results from the Tromsø study. J Stud Alcohol 1999; 60: 111-9.

Schirmer H, Lunde P, Rasmussen K. Prevalence of left ventricular hypertrophy in a general population. The Tromsø Study. Eur Heart J 1999; 20: 428-437. (IV)

Schirmer H, Omland T. Circulation N-terminal pro-atrial natriuretic peptide is an independent predictor of left ventricular hypertrophy in the general population. The Tromsø Study. Eur Heart J 1999; 20: 755-763. (IV)

Schirmer H, Lunde P, Rasmussen K. What determines echogenisity in a general population? J Am Soc Echocardiography 1999; 12: 314-318. (IV)

Smith-Sivertsen T, Dotterud LK, Lund E. Nickel allergy and its relationship with local nickel pollution, ear piercing, and atopic dermatitis: A population-based study from Norway. J Am Acad Dermatol 1999; 40: 726735. (IV)

Thune I, Njølstad I, Løchen ML. Cardiovascular risk factors and physical activity: how much is enough? Letter. Arch Intern Med 1999; 159: 882-883.

Toft I, Bønaa KH, Lindal S, Berg TJ, Jenssen T. Population-based study of the relationship among muscle morphology, insulin action, and hypertension. Am J Hypertens 1999; 12: 1209-1216. (III)

\section{0:}

Berntsen GKR, Fønnebø V, Tollan A, Søgaard AJ, Joakimsen RM, Magnus JH. The Tromsø Study: Determinants of precision in bone densitometry. J Clin Epidemiol 2000; 53: 1104-12. (IV)

Engstad T, Bønaa KH, Viitanen M. Validity of self-reported stroke. The Tromsø Study. Stroke 2000; 31: 16021607. (IV)

Jacobsen BK, Nilsen H. High education is associated with low fat and high fibre, beta-carotene and vitamin C. Computation of nutrient intake based on a short food frequency questionnaire in 17,256 men and women in the Tromsø Study. Norsk Epidemiologi 2000; 10: 57-62.

Joakimsen O, Bønaa KH, Stensland-Bugge E, Jacobsen BK. Population-based study of age at menopause and ultrasound assessed carotid atherosclerosis. The Tromsø Study. J Clin Epidemiol 2000; 53: 525-530. (IV)

Joakimsen O, Bønaa KH, Mathiesen EB, Stensland-Bugge E, Arnesen E. Prediction of mortality by ultrasound screening of a general population for carotid stenosis. The Tromsø Study. Stroke 2000; 31: 1871-1876. (IV)

Jorde R, Bønaa KH. Calcium from dairy products, vitamin D intake, and blood pressure: The Tromsø Study. Am J Clin Nutr 2000; 71: 1530-1535. (IV)

Jorde R, Sundsfjord J, Haug E, Bønaa KH. Relation between low calcium intake, parathyroid hormone, and blood pressure. Hypertension 2000; 35: 1154-1159. (IV)

Jorde R, Sundsfjord J. Bone mineral density and blood pressure in patients with asymptomatic hyperparathyroidism. The Tromsø Study. J Intern Med 2000; 247: 325-330. (IV)

Jorde R, Bønaa KH, Sundsfjord J. Primary hyperparathyroidism detected in a health screening. The Tromsø Study. J Clin Epidemiol 2000; 53: 1164-9 (IV).

Mathiesen EB, Joakimsen O, Bønaa KH. Intersonographer reproducibility and intermethod variability of ultrasound measurements of carotid artery stenosis. The Tromsø Study. Cerebrovasc Dis 2000; 10: 207-213 (IV) 
Schirmer H, Lunde P, Rasmussen K. Mitral flow derived Doppler indices of left ventricular diastolic function. The Tromsø Study. Eur Heart J 2000; 21: 1376-1386. (IV)

Stensland-Bugge E, Bønaa KH, Joakimsen O, Njølstad I. Sex differences in the relationship of risk factors to subclinical carotid atherosclerosis measured 15 years later. The Tromsø Study. Stroke 2000; 31: 574-581. (II, IV)

Wilsgaard T, Schirmer H, Arnesen E. Impact of body weight on blood pressure with a focus on gender differences. The Tromsø Study 1986 - 1995. Arch Intern Med 2000; 160: 2847-2853. (III, IV)

\section{1:}

Berntsen GKR, Fønnebø V, Tollan A, Søgaard AJ, Magnus JH. The Tromsø Study: A population-based study of forearm bone mineral density by age, in 7620 men and women. Am J Epidemiol 2001; 153: 465-73. (IV)

Hansen V, Jacobsen BK, Arnesen E. Prevalence of serious psychiatric morbidity in attenders and nonattenders to a health survey of a general population: the Tromsø Health Study. Am J Epidemiol 2001; 154: 891-4. (II)

Jacobsen BK, Njølstad I, Thune I, Wilsgaard T, Løchen ML, Schirmer H. Increase in weight in all birth cohorts in a general population. The Tromsø Study 1974-1994. Arch Intern Med 2001; 161: 466-472. (I, II, III, IV)

Joakimsen RM, Fønnebø V, Søgaard AJ, Tollan A, Størmer J, Magnus JH. The Tromsø Study: registration of fractures, how good are self-reports, a computerized radiographic register and a discharge register? Osteopor Int 2001; 12: 1001-5. (III)

Jorde R, Sundsfjord J, Bønaa KH. Determinants of serum calcium in men and women. The Tromsø Study. Eur J Epidemiol 2001; 17: 1117-23.

Jørgensen L, Engstad T, Jacobsen BK. Bone mineral density in acute stroke patients: low bone mineral may predict first stroke in women. Stroke 2001; 32: 47-51. (IV)

Mathiesen EB, Joakimsen O, Bønaa KH. Prevalence of and risk factors associated with carotid artery stenosis. The Tromsø Study. Cerebrovasc Dis 2001; 12: 44-50. (IV)

Mathiesen EB, Bønaa KH, Joakimsen O. Echolucent plaques are associated with high risk of ischemic cerebrovascular events in carotid stenosis. The Tromsø Study. Circulation 2001; 103: 2171-2175. (IV)

Mathiesen EB, Bønaa KH, Joakimsen O. Low levels of high-density lipoprotein cholesterol are associated with echolucent carotid artery plaques: The Tromsø Study. Stroke 2001; 32: 1960-5. (IV)

Midtby M, Magnus JG, Joakimsen RM. The Tromsø Study: a population-based study on the variation in bone formation markers with age, gender, anthropometry and season in both men and women. Osteoporos Int 2001; 12: 835-43. (IV)

Singh K, Bønaa KH, Jacobsen BK, Bjørk L, Solberg S. Prevalence of and risk factors for abdominal aortic aneurysms in a population-based study: the Tromsø Study. Am J Epidemiol 2001; 154: 236-44. (IV)

Stensland-Bugge E, Bønaa KH, Joakimsen O. Age and sex differences in inherited and lifestyle risk factors for subclinical atherosclerosis. The Tromsø Study. Atherosclerosis 2001; 154; 437-448. (IV)

Wilsgaard T, Jacobsen BK, Schirmer H, Thune I, Løchen ML, Njølstad I, Arnesen E. Tracking of cardiovascular risk factors. The Tromsø Study, 1979-1995. Am J Epidemiol 2001; 154: 418-426. (II, III, IV)

\section{2:}

Isaksen J, Egge A, Waterloo K, Rommer B, Ingebrigtsen T. Risk factors for aneurysmal subarachnoid haemorrhage: the Tromsø study. J Neurol Neurosurg Psychiatry 2002; 73: 185-7. (IV)

Halvorsen DS, Børvik T, Njølstad I, Gutteberg TJ, Vorland LH, Hansen JB. Chlamydia pneumoniae IgA- and IgG antibodies in young survivors of myocardial infarction. A comparison of antibody detection by a microimmunofluorescence test and an enzyme immunoassay. J Intern Med 2002; 251: 142-7. (IV)

Jacobsen BK, Bønaa KH, Njølstad I. Cardiovascular risk factors, change in risk factors over 7 years, and the risk of clinical diabetes mellitus type 2. The Tromsø Study. J Clin Epidemiol 2002; 55: 647-53. (II, III, IV)

Jorde R, Szumlas K, Haug E, Sundsfjord J. The effects of calcium supplementation to patients with hyperparathyroidism and a low calcium intake. Eur J Nutr 2002; 41: 258-63. (IV)

Jørgensen L, Engstad T, Jacobsen BK. Higher incidence of falls in long-term stroke survivors than in population controls: depressive symptoms predict falls after stroke. Stroke 2002; 33: 321-2. (IV)

Mathiesen EB. The role of plaque echogenicity in carotid stenosis: Increased risk of ischemic stroke in persons with echolucent plaques. Cardiovasc Rev Rep 2002; 23: 561-4. 
Mathiesen EB, Bønaa KH, Joakimsen O. Cholesterol and carotid stenosis (Authors reply). Stroke 2002; 33: $321-2$.

Prospective Studies Collaboration. Age-specific relevance of usual blood pressure to vascular mortality: a metaanalysis of individual data for one million adults in 61 prospective studies. Lancet 2002; 360; 1903-13. (II)

Skjelbakken T, Løchen ML, Dahl IM. Haematological malignancies in a general population, based on information collected from a population study, hospital records, and the cancer Registry of Norway: the Tromsø Study. Eur J Haematol 2002; 69: 67-75. (IV)

The Homocysteine Studies Collaboration. Homocysteine and risk of ischemic heart disease and stroke. A metaanalysis. JAMA 2002; 288: 2015-20. (III)

Toft I, Bønaa KH, Eikrem J, Bendiksen AL, Iversen H, Jenssen T. Microalbuminuria in hypertension is not a determinant of insulin resistance. Kidney Int 2002; 61: 1445-52. (IV)

Wilsgaard T, Jacobsen BK, Schirmer H, Thune I, Løchen ML, Njølstad I, Arnesen E. Re: Tracking of cardiovascular risk factors. The Tromsø Study, 1979-1995 (The authors' reply). Am J Epidemiol 2002; 155; 1145. 